\title{
Endogenous myoglobin in human breast cancer is a hallmark of luminal cancer phenotype
}

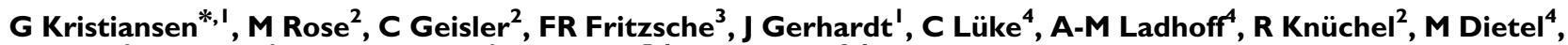 \\ H Moch', Z Varga', J-P Theurillat', TA Gorr ${ }^{5,6}$ and E Dahl ${ }^{2,6}$ \\ 'Institute of Surgical Pathology, University Hospital Zurich, Schmelzbergstrasse 12, 809 I Zurich, Switzerland; ' Institute of Pathology, University Hospital \\ of the RWTH, Aachen, Germany; ${ }^{3}$ Institute of Veterinary Physiology, Vetsuisse Faculty, University of Zurich, Zurich, Switzerland; ${ }^{4}$ Institute of Pathology, \\ Charité - Universitätsmedizin Berlin, Berlin, Germany; ${ }^{5}$ Institute of Veterinary Physiology, University of Zurich, Zurich, Switzerland
}

BACKGROUND: We aimed to clarify the incidence and the clinicopathological value of non-muscle myoglobin (Mb) in a large cohort of non-invasive and invasive breast cancer cases.

METHODS: Matched pairs of breast tissues from 10 patients plus 17 breast cell lines were screened by quantitative PCR for Mb mRNA. In addition, 917 invasive and 155 non-invasive breast cancer cases were analysed by immunohistochemistry for Mb expression and correlated to clinicopathological parameters and basal molecular characteristics including oestrogen receptor- $\alpha(E R \alpha) / p r o g e s t e r o n$ receptor (PR)/HER2, fatty acid synthase (FASN), hypoxia-inducible factor- $\alpha$ (HIF- | $\alpha)$, HIF-2 $\alpha$, glucose transporter I (GLUTI) and carbonic anhydrase IX (CAIX). The spatial relationship of Mb and ER $\alpha$ or FASN was followed up by double immunofluorescence. Finally, the effects of estradiol treatment and FASN inhibition on Mb expression in breast cancer cells were analysed.

RESULTS: Myoglobin mRNA was found in a subset of breast cancer cell lines; in microdissected tumours Mb transcript was markedly upregulated. In all, 7 I\% of tumours displayed Mb protein expression in significant correlation with a positive hormone receptor status and better prognosis. In silico data mining confirmed higher Mb levels in luminal-type breast cancer. Myoglobin was also correlated to FASN,

HIF- $2 \alpha$ and CAIX, but not to HIF- $\mid \alpha$ or GLUTI, suggesting hypoxia to participate in its regulation. Double immunofluorescence showed a cellular co-expression of ER $\alpha$ or FASN and Mb. In addition, Mb levels were modulated on estradiol treatment and FASN inhibition in a cell model.

CONCLUSION: We conclude that in breast cancer, $\mathrm{Mb}$ is co-expressed with $\mathrm{ER} \alpha$ and co-regulated by oestrogen signalling and can be considered a hallmark of luminal breast cancer phenotype. This and its possible new role in fatty acid metabolism may have fundamental implications for our understanding of $\mathrm{Mb}$ in solid tumours.

British Journal of Cancer (2010) I 02, 1736- 1745. doi:I0.1038/sj.bjc.6605702 www.bjcancer.com

(c) 2010 Cancer Research UK

Keywords: breast cancer; myoglobin; oestrogen receptor; fatty acids; luminal type

Human myoglobin $(\mathrm{Mb})$ is considered to be one of the bestcharacterised proteins, with more than 11200 PubMed-listed publications, since Kendrew and co-workers presented the first three-dimensional model of this molecule in 1958 (Kendrew, 1958). It is commonly described as a cytoplasmic hemoprotein that is solely occurring at milli- to micromolar concentrations in cardiac myocytes and type I and IIa skeletal muscle fibres of mammals. In myocytes, $\mathrm{Mb}$ is widely accepted to function as temporary 'store' for oxygen $\left(\mathrm{O}_{2}\right)$, able to buffer short phases of exercise-induced increases in $\mathrm{O}_{2}$ flux during which it supplies the gas to mitochondria (Ordway and Garry, 2004). Another, more controversially discussed role is Mbs' facilitation of $\mathrm{O}_{2}$ diffusion

*Correspondence: Dr G Kristiansen; E-mail: glen.kristiansen@usz.ch This paper was presented in part at the $\mathrm{XV}$ International Conference on Dioxygen Binding and Sensing Proteins Meeting in Aarhus, Denmark, 2008.

${ }^{6}$ These two authors are co-senior authors.

Received 8 March 2010; revised 12 April 20 I0; accepted 26 April 2010 within muscle cells (Wittenberg, 1970; Jürgens et al, 1994). Although $\mathrm{Mb}$ knockout mice exhibited normal exercise capacity and no signs of compromised cardiac energetics due to multiple systemic compensations (Garry et al, 1998; Gödecke et al, 1999), follow-up studies stressed the importance of functional $\mathrm{Mb}$ in maintaining nitric oxide (NO) homeostasis in muscle through either scavenging (Flögel et al, 2001) or producing the NO molecule (Hendgen-Cotta et al, 2008). That way, Mb might participate in tuning vasodilatory responsiveness and protecting the respiratory chain from NO inhibition (Brunori, 2001). Further possible functions of $\mathrm{Mb}$ in muscle include synthesis of peroxides (Khan et al, 1998), scavenging of reactive $\mathrm{O}_{2}$ species (Flögel et al, 2004) and binding of fatty acids (FAs) (Masuda et al, 2008).

In humans, $\mathrm{Mb}$ is synthesised at concentrations of $\sim 200-300 \mu \mathrm{M}$ in striated muscle and, although at much lower levels, in a variety of human tumours including medullomyoblastoma (Smith and Davidson, 1984), thymolipoma (Iseki et al, 1990), acute leukaemia (Ruck et al, 1995) and desmoplastic small round cell tumours (Zhang et al, 2003). Following an accidental 
observation of positive $\mathrm{Mb}$ staining in several human carcinomas in 2001, we have systematically examined Mb expression in human breast cancer. Very recently, Flonta et al (2009) described Mb in solid tumours including 31 breast cancer cases; however, this small cohort size precluded further statistical analyses. Now, we are presenting the first comprehensive analysis of $\mathrm{Mb}$ expression in a large and representative cohort of human breast tissues encompassing normal tissue $(n=56)$, ductal carcinoma in situ (DCIS, $n=155)$, invasive breast cancer $(n=917)$ and breast cancer recurrences $(n=76)$, enabling a portrayal of the associations between clinicopathological parameters and the range of $\mathrm{Mb}$ synthesis seen in mammary carcinomas. We also shed some light on unusual functions of $\mathrm{Mb}$ in cancer by looking at the impact of steroids on the steady state level of the protein and by examining Mb's involvement in FA metabolism.

\section{MATERIALS AND METHODS}

\section{Clinical materials and patients}

The matched tumour/normal samples of invasive ductal breast carcinomas and corresponding normal breast epithelium $(n=10)$ analysed in this study have recently been described (Veeck et al, 2006). For immunohistochemistry, our study included tissue microarrays of normal tissue, intratumoural DCIS, invasive breast cancer and breast cancer recurrences of patients diagnosed at the Institute of Surgical Pathology (University Hospital, Zurich, Switzerland), as described (Theurillat et al, 2007). Tumour histology was determined according to the criteria of the (Tavassoli and Devilee, 2003), whereas staging the disease followed (Sobin and Wittekind, 2002). Tumours were graded according to Bloom and Richardson, as modified by Elston and Ellis (1993). Clinicopathological characteristics of the patients/tumours are given in Table 1. For statistical analysis, only cases with clinical follow-up data were considered. The median observation time for overall survival was 59 months for patients still alive at the time of analysis. In total, 225 patients (24\%) died during follow-up. Data on adjuvant therapy was not available. Appropriate review board consent has been obtained to allow the use of these materials for research purposes.

\section{Cell lines}

The human mammary epithelial cell line MCF12A, as well as the breast cancerous cell lines BT20, BT474, Cal51, EFM19, HBL100, Hs578T, MDA-MB231, MDA-MB361, MDA-MB453, MDA-MB415, MDA-MB436, MDA-MB468, MCF7, SKBR3, T47-D and ZR75-1 were obtained from the ATCC (Rockville, MD, USA) and cultured under recommended conditions.

\section{Quantitative real-time reverse transcription PCR}

For quantitative PCR experiments, we used the ABI Prism 7500 Fast SDS (Applied Biosystems, Darmstadt, Germany) with the following primers: $\mathrm{Mb}$ (111 bp) 5'-GGCATCATGAGGCAGA GATT-3' and 5'-TCTGCAGAACCTGGATGATG-3'; glyceraldehyde

Table I Clinicopathological parameters of invasive breast cancer cases and relation to myoglobin expression

\begin{tabular}{|c|c|c|c|c|c|c|}
\hline Characteristic & Number of cases (\%) & Mb negative & Mb weak & Mb moderate & Mb strong & $P$-value \\
\hline $\begin{array}{l}<60 \text { years } \\
\geqslant 60 \text { years }\end{array}$ & $\begin{array}{l}917(100 \%) \\
416(45.4 \%) \\
501(54.6 \%)\end{array}$ & $\begin{array}{l}125 \\
142\end{array}$ & $\begin{array}{l}132 \\
157\end{array}$ & $\begin{array}{l}130 \\
142\end{array}$ & $\begin{array}{l}29 \\
60\end{array}$ & $0.170^{\mathrm{a}}$ \\
\hline $\begin{array}{l}\text { Pre-menopausal } \\
\text { Post-menopausal }\end{array}$ & $\begin{array}{l}198(21.5 \%) \\
719(78.5 \%)\end{array}$ & $\begin{array}{r}67 \\
200\end{array}$ & $\begin{array}{r}64 \\
225\end{array}$ & $\begin{array}{r}60 \\
212\end{array}$ & $\begin{array}{r}7 \\
82\end{array}$ & $0.007^{\mathrm{a}}$ \\
\hline $\begin{array}{l}\text { Invasive ductal } \\
\text { Invasive lobular } \\
\text { NOS }\end{array}$ & $\begin{array}{c}739(80.6 \%) \\
125(13.6 \%) \\
53(5.8 \%)\end{array}$ & $\begin{array}{r}214 \\
39 \\
14\end{array}$ & $\begin{array}{r}221 \\
49 \\
19\end{array}$ & $\begin{array}{r}228 \\
29 \\
15\end{array}$ & $\begin{array}{r}76 \\
8 \\
5\end{array}$ & $0.375^{b}$ \\
\hline $\begin{array}{l}\text { PTI } \\
\text { PT2 } \\
\text { PT3 } \\
\text { PT4 }\end{array}$ & $\begin{array}{c}335(36.5 \%) \\
410(44.7 \%) \\
66(7.2 \%) \\
106(11.6 \%)\end{array}$ & $\begin{array}{r}91 \\
115 \\
27 \\
34\end{array}$ & $\begin{array}{r}108 \\
134 \\
19 \\
28\end{array}$ & $\begin{array}{r}106 \\
119 \\
17 \\
30\end{array}$ & $\begin{array}{r}30 \\
42 \\
3 \\
14\end{array}$ & $0.479^{a}$ \\
\hline $\begin{array}{l}\mathrm{pN} 0 \\
\mathrm{pNI} \\
\mathrm{pN} 2 \\
\mathrm{pN} 3\end{array}$ & $\begin{array}{c}346(42.5 \%) \\
369(45.3 \%) \\
69(8.5 \%) \\
31(3.8 \%)\end{array}$ & $\begin{array}{r}92 \\
113 \\
21 \\
10\end{array}$ & $\begin{array}{r}107 \\
120 \\
20 \\
8\end{array}$ & $\begin{array}{r}111 \\
105 \\
16 \\
12\end{array}$ & $\begin{array}{r}36 \\
31 \\
12 \\
1\end{array}$ & $0.355^{\mathrm{a}}$ \\
\hline $\begin{array}{l}\text { G1 } \\
\text { G2 } \\
\text { G3 }\end{array}$ & $\begin{array}{l}126(13.7 \%) \\
460(50.2 \%) \\
331(36.1 \%)\end{array}$ & $\begin{array}{r}30 \\
112 \\
125\end{array}$ & $\begin{array}{r}40 \\
155 \\
94\end{array}$ & $\begin{array}{r}46 \\
141 \\
85\end{array}$ & $\begin{array}{l}10 \\
52 \\
27\end{array}$ & $0.001^{\mathrm{a}}$ \\
\hline $\begin{array}{l}\text { ER negative } \\
\text { ER positive }\end{array}$ & $\begin{array}{l}163(18.7 \%) \\
709(81.3 \%)\end{array}$ & $\begin{array}{r}78 \\
17 \mid\end{array}$ & $\begin{array}{r}45 \\
226\end{array}$ & $\begin{array}{r}34 \\
231\end{array}$ & $\begin{array}{r}6 \\
81\end{array}$ & $0.001^{\mathrm{a}}$ \\
\hline $\begin{array}{l}\text { PR negative } \\
\text { PR positive }\end{array}$ & $\begin{array}{l}314(34.8 \%) \\
588(65.2 \%)\end{array}$ & $\begin{array}{l}114 \\
145\end{array}$ & $\begin{array}{l}104 \\
183\end{array}$ & $\begin{array}{r}82 \\
187\end{array}$ & $\begin{array}{l}14 \\
73\end{array}$ & $0.001^{\mathrm{a}}$ \\
\hline $\begin{array}{l}\text { HER2 }-0,1+, 2+ \\
\text { HER2 }-3+\end{array}$ & $\begin{array}{l}776(88.1 \%) \\
105(11.9 \%)\end{array}$ & $\begin{array}{r}223 \\
33\end{array}$ & $\begin{array}{r}241 \\
37\end{array}$ & $\begin{array}{r}239 \\
25\end{array}$ & $\begin{array}{l}73 \\
10\end{array}$ & $0.346^{\mathrm{a}}$ \\
\hline $\begin{array}{l}K i-67 \leqslant 10 \% \\
K i-67>10 \%\end{array}$ & $\begin{array}{l}466(54 \%) \\
393(46 \%)\end{array}$ & $\begin{array}{l}132 \\
117\end{array}$ & $\begin{array}{l}149 \\
115\end{array}$ & $\begin{array}{l}139 \\
121\end{array}$ & $\begin{array}{l}46 \\
40\end{array}$ & $0.985^{\mathrm{a}}$ \\
\hline $\begin{array}{l}\text { CK5/6 negative } \\
\text { CK5/6 positive }\end{array}$ & $\begin{array}{r}793 \\
96\end{array}$ & $\begin{array}{r}212 \\
45\end{array}$ & $\begin{array}{r}260 \\
22\end{array}$ & $\begin{array}{r}239 \\
26\end{array}$ & $\begin{array}{r}82 \\
3\end{array}$ & $0.001^{a}$ \\
\hline
\end{tabular}

Abbreviations: $E R=$ oestrogen receptor; $\mathrm{Mb}=$ myoglobin; NOS = not otherwise specified; PR $=$ progesteron receptor. ${ }^{\mathrm{a}} \chi^{2}$-test for trends. ${ }^{\mathrm{b}}$ Pearson's $\chi^{2}$-test. 
3-phosphate dehydrogenase (289 bp) $5^{\prime}$-GAAGGTGAAGGTCGGA GTCA- $3^{\prime}$ and $5^{\prime}$-TGGACTCCACGACGTACTCA- $3^{\prime} ; \beta$-actin $(185 \mathrm{bp})$ $5^{\prime}$-GGACGACATGGAGAAAATC- $3^{\prime}$ and $5^{\prime}$-ATAGCACAGCCTGGA TAGC- $3^{\prime}$.

\section{Western blots}

MDA-MB468 cells were harvested with a lysis buffer containing $0.1 \%$ NP-40, $400 \mathrm{~mm} \mathrm{NaCl}, 1 \mathrm{~mm}$ EDTA ( $\mathrm{pH} 8.0$ ), $10 \mathrm{~mm}$ Tris-HCl $(\mathrm{pH} 8.0)$ and protease inhibitors. Protein extracts were electrophoresed on a $15 \%$ SDS-PAGE gel. Monoclonal antibody mouse anti-Mb (clone Z001, Zymed Laboratories, San Francisco, CA, USA) was used for immunoblotting ( $1: 1000$ dilution). For equal loading control, blots were stripped and re-probed by monoclonal antibody mouse anti- $\beta$-actin at a 1:5000 dilution (no. A5441, Sigma-Aldrich, Basel, Switzerland).

\section{Immunohistochemistry and immunofluorescence}

Tissue sections were processed using automated immunohistochemistry platforms (BOND, Labvision (Fremont, CA, USA) and Benchmark, Ventana (Tucson, AZ, USA)) using the following antibodies and dilutions: $\mathrm{Mb}$, clone Z001, Zymed Laboratories (1:300); fatty acid synthase (FASN), clone 3F2-1F3, Abnova (Taipei, Taiwan) (1:2000); HIF- $1 \alpha$, clone mgc3, Abcam (Cambridge, UK) $(1: 400)$; HIF- $2 \alpha$, rabbit polyclonal, Novus Biologicals (Littleton, CO, USA) (1:150); glucose transporter 1 (GLUT1), rabbit polyclonal, Chemicon (Temecula, CA, USA) (1:1000); carbonic anhydrase IX (CAIX), rabbit polyclonal, Abcam $(1: 300)$. Immunohistochemistry was evaluated by two clinical pathologists (GK, Florian Rudolf Fritzsche). Intensity of $\mathrm{Mb}$, GLUT1, CAIX and FASN was semiquantitatively scored as negative, weakly, moderately or strongly positive $(0-3+)$. Oestrogen receptor $-\alpha(\mathrm{ER} \alpha) /$ progesterone receptor (PR)/HIFs were evaluated in percent of positive nuclei. Double immunofluorescence (Mb/ER and $\mathrm{Mb} / \mathrm{FASN})$ was performed as described (Kristiansen et al, 2008).

\section{Electron microscopy}

Tissues from two breast tumours were fixed with $2.5 \%$ glutaraldehyde, postfixed with osmium tetroxide, embedded in epoxy resin, cut with an ultramicrotome, mounted on 200 mesh copper grids, stained with uranyl acetate and lead citrate and examined with a Zeiss EM10 transmission electron microscope (Zeiss, Oberkochen, Germany) at $60 \mathrm{kV}$.

\section{Expression of Mb gene after incubation of MCF-7 cells with $\beta$-estradiol}

MCF7 cells $\left(8 \times 10^{5}\right)$ were seeded into a $10 \mathrm{~cm}$ culture dish, and $24 \mathrm{~h}$ later, 17- $\beta$-estradiol (Sigma-Aldrich, Deisenheim, Germany) dissolved in $5 \mu \mathrm{l}$ absolute ethanol was applied to the cells at a final concentration of $0 \mathrm{pm}, 20 \mathrm{pm}, 40 \mathrm{pm}$ and $60 \mathrm{pm}$. Cells without $17-\beta$ estradiol and ethanol served as internal control.

\section{Expression of $\mathrm{Mb}$ gene after incubation of MDA-MB-468 cells with the FASN inhibitor C75}

MDA-MB-468 cells $\left(3 \times 10^{5}\right)$ were seeded into six-well plates and exposed to $10 \mu \mathrm{g} \mathrm{ml}^{-1}$ final concentration of the FASN inhibitor C75 (Sigma-Aldrich, St Louis, MO, USA) for 8, 24 and $48 \mathrm{~h}$. The RNA and proteins were isolated according to standard procedures.

\section{Statistical analysis}

Expression data were analysed using the software package SPSS, version 16.0 (SPSS Inc, Chicago, IL, USA). Fisher's exact and $\chi^{2}$-tests for trends were used to assess the statistical significance of associations between $\mathrm{Mb}$ expression and clinicopathological parameters (Table 1). Univariate survival analysis was performed with univariate Cox analyses and Kaplan-Meier curves (Log-rank test). Bivariate correlations according to Spearman were applied to the immunointensity of normal tissue, intraductal and invasive carcinomas.

\section{RESULTS}

\section{Human breast cancer tissue exerts a complex pattern of Mb expression}

$M b$ is detectable on mRNA level in cell lines and human breast tumours Following the initial observation of $\mathrm{Mb}$ immunoreactivity in conventional immunohistochemistry analyses, $\mathrm{Mb}$ transcript levels were determined in breast biopsies and breast cell lines. Whereas low levels of $\mathrm{Mb}$ mRNA were detectable in 4 of 10 cases of healthy breast tissue (Figure $1 \mathrm{~A}$ ), Mb expression was upregulated in 9 of 10 matched normal/tumour tissue samples with a median tumour-to-normal upregulation of 352-fold. With regard to breast cell lines, $\mathrm{Mb}$ mRNA was not detectable in benign MCF12A epithelial cells, as well as in MDA-MB436, Hs578T and Cal51 tumour cells (Figure 1B). In all, 10 breast cancer cell lines (MDA-MB231 to MCF7, Figure 1B) expressed detectable but low amounts of $\mathrm{Mb}$ mRNA, whereas 3 breast cancer cell lines contained abundant quantities of the Mb transcript, that is, EFM19, MDA-MB415 and MDA-MB468 cells. Regarding the protein abundance, we used a commercial chemiluminescence-based $\mathrm{Mb}$ assay and determined the amount of $\mathrm{Mb}$ protein present in normoxic $10^{6} \mathrm{MDA}-\mathrm{MB} 468$ cells to correspond to $\sim 65 \mathrm{ng}$ or $4 \mathrm{pmol}$ (which, assuming a mean cell diameter of $20 \mu \mathrm{m}$ and sphere shaped cells, roughly corresponds to a $\mathrm{Mb}$ concentration estimate in the low $\mu \mathrm{M}$ range).

Large-scale immunohistochemical analysis of $M b$ protein in breast tissues Using a validated monoclonal $\mathrm{Mb}$ antibody (Supplementary Figure S1), we next analysed Mb expression on tissue microarrays containing normal tissue $(n=56)$, intratumoural DCIS $(n=155)$, invasive breast cancer $(n=917$, clinicopathological parameters are given in Table 1) and 76 recurrences of invasive tumours. In normal breast tissue, staining was observed in secretory luminal epithelial cells, but not in myoepithelial cells (Figure 1C, arrowhead), with single secretory cells (bold arrow) staining considerably stronger than adjacent secretory cells (Figure 1C, thin arrow). Altogether, in normal breast tissue, $7 \%$ of cases were completely negative for $\mathrm{Mb}, 49 \%$ were weakly positive, $39 \%$ stained moderately positive and $5 \%$ of tissues stained strongly (Supplementary Figure S2). Ductal carcinoma in situ showed altogether a more abundant $\mathrm{Mb}$ staining (Figure 1D): $12 \%$ of DCIS cases were negative, $38 \%$ weakly positive, $39 \%$ moderately positive and $11 \%$ were strongly positive. In invasive carcinoma, the number of $\mathrm{Mb}$-negative cases was markedly higher than in normal tissue: $29 \%$ were negative, $32 \%$ were weakly positive, $30 \%$ were moderately positive (Figure 1E) and $9 \%$ were strongly positive (Figure $1 \mathrm{~F}$ ). A spotted, mosaic-like expression pattern was frequently seen in DCIS and invasive carcinoma (Figure 1E). In tumour recurrences, $30 \%$ cases were $\mathrm{Mb}$ negative, $22 \%$ weakly positive, $33 \%$ moderately positive and $15 \%$ stained strongly (Supplementary Figure S2). Apparently, although the mean $\mathrm{Mb}$ positivity is not significantly altered during malignant progression, an increasing polarisation in $\mathrm{Mb}$ expression is noted in the increased number of negative and strongly positive cases from normal tissue to tumour recurrences. 
A
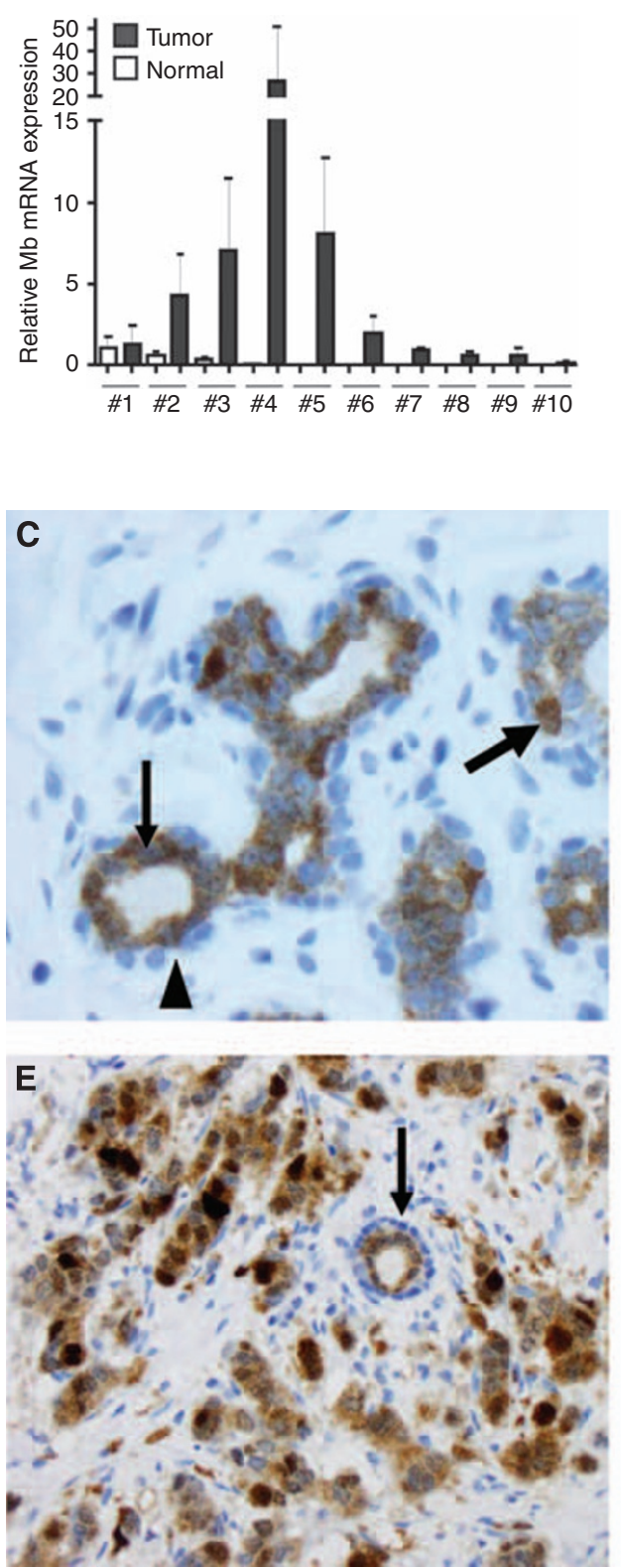

B
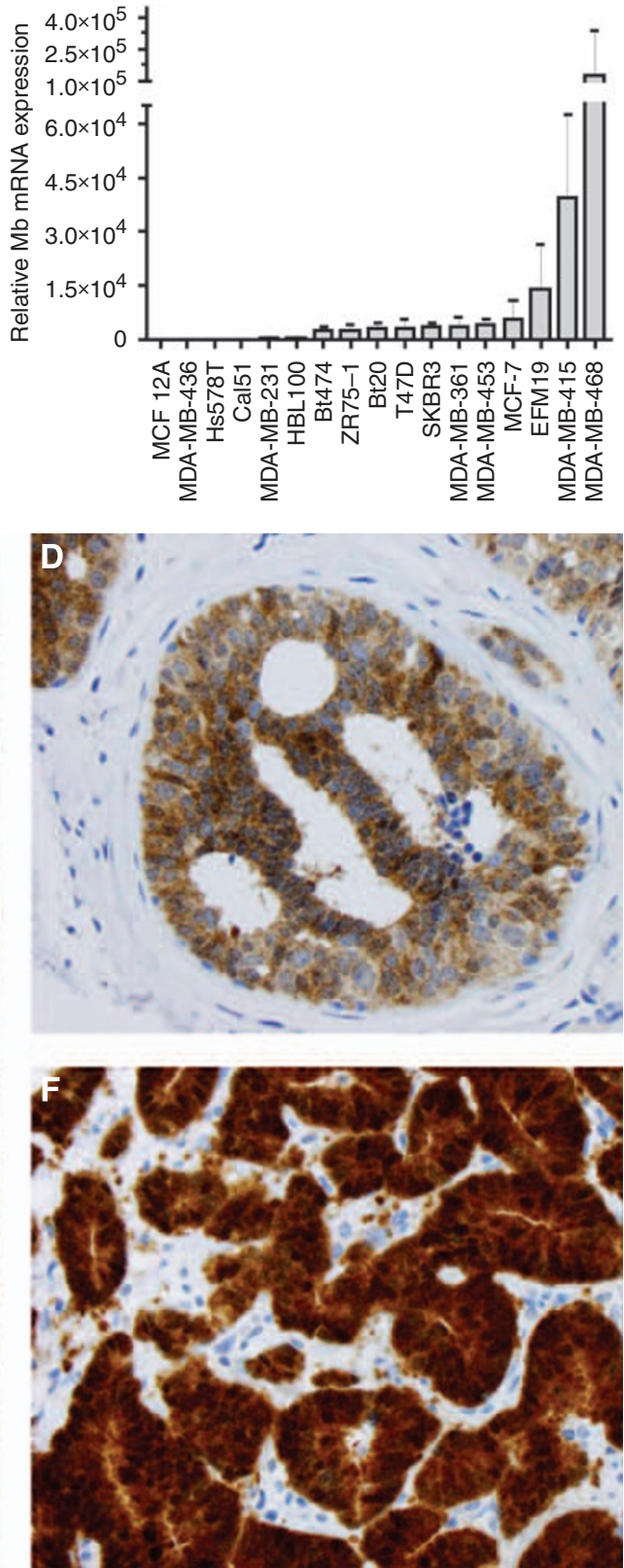

Figure I Detection of myoglobin (Mb) mRNA and protein in clinical breast cancer samples and cell lines. (A) MB mRNA expression in I0 randomly chosen samples of human breast cancer and corresponding normal breast tissues (no. I to no. 10), as measured by quantitative RT-PCR. Calculation of error bars according to Applied Biosystems user manual. Median myoglobin expression was up to 352-fold upregulated in breast tumours (grey) compared with matching normal breast tissues (white). (B) Myoglobin mRNA expression in benign MCFI2A breast cells and various breast cancer cell lines. (C) Normal lobular parenchyma of the breast, illustrating a mild $\mathrm{Mb}$ immunoreactivity in luminal epithelial cells (inner layer, thin arrow), whereas myoepithelial cells (outer cell layer, arrowhead) are negative. Note, that single luminal cells (bold arrow) are highlighted by a stronger Mb immunostaining $(\times 400)$. $(\mathbf{D})$ Strong myoglobin positivity in a ductal carcinoma in situ (DCIS), low grade, tissue showing a slight accentuation of staining in the centre in support of $\mathrm{O}_{2}$-diffusion gradients contributing to the $\mathrm{Mb}$ expression profile in tissues $(\times 200)$. (E and $\mathbf{F})$ Examples of invasive ductal carcinoma of the breast (all $\times 200)$. (E) Moderately differentiated with a moderate-to-strong and patchy Mb expression. In addition, note the central normal duct (arrow) with the Mb-positive secretory cell layer and the Mb-negative myoepithelial layer. (F) Strong Mb immunoreactivity in a well-differentiated carcinoma.

\section{Electron microscopy: $\mathrm{Mb}$ is found without striated muscle elements}

As $\mathrm{Mb}$ has been described as a marker of rhabdomyoid differentiation, we analysed two breast tumours with strong $\mathrm{Mb}$ immunoreactivity by transmission electron microscopy (Supplementary Figure S3A and B). However, no striated muscle elements could be observed in these cases, suggesting that increased expression of $\mathrm{Mb}$ occurs independently of rhabdomyoid tumour differentiation.
$\mathrm{Mb}$ expression in invasive breast cancer shows a complex correlative pattern to endogenous markers of Hypoxia (HIF-1 $\alpha$, HIF- $2 \alpha$, GLUT1 and CAIX)

A subset of invasive breast cancer cases $(n=150)$ was additionally analysed for protein level expression of the hypoxiainducible (transcription) factors $1 \alpha$ and $2 \alpha$ (HIF- $1 \alpha$, HIF- $2 \alpha$ ), which are generally considered as the key regulators of the hypoxic response in cells and tissues, and their down stream targets GLUT1 and CAIX. Myoglobin expression correlated 
Table 2 Correlation of myoglobin expression to endogenous markers of hypoxia (cc; P-value)

\begin{tabular}{lcccc}
\hline & HIF-I $\boldsymbol{\alpha}$ & HIF-2 $\boldsymbol{\alpha}$ & GLUTI & CAIX \\
\hline Mb & $0.095 ; 0.276$ & $0.293 ; 0.001$ & $-0.039 ; 0.64$ & $0.286 ; 0.001$ \\
HIF- I $\alpha$ & & $0.215 ; 0.020$ & $0.334 ; 0.001$ & $0.285 ; 0.001$ \\
HIF-2 $\alpha$ & & & $-0.206 ; 0.024$ & $0.223 ; 0.015$ \\
GLUTI & & & & $0.252 ; 0.003$ \\
\hline
\end{tabular}

Abbreviations: $\mathrm{CIAX}=$ carbonic anhydrase $|\mathrm{X} ; \mathrm{GLUT}|=$ glucose transporter $\mathrm{HIF}=$ hypoxia-inducible factor.

significantly with HIF- $2 \alpha$ and CAIX, but failed to correlate with HIF- $1 \alpha$ or GLUT1 (Table 2).

\section{Tumour-derived $\mathrm{Mb}$ expression is linked to oestrogen receptor status and better prognosis, and may represent a marker for luminal-type breast cancer}

In invasive breast carcinomas, $\mathrm{Mb}$ expression was associated with better histological tumour differentiation according to BRE grading (correlation coefficient $(\mathrm{cc})=-0.116 ; P=0.001$ ). Myoglobin did not correlate with $\mathrm{pT}$ stage, nodal status or tumour type. Myoglobin expression was positively correlated with $\mathrm{ER} \alpha$ and PR positivity ( $c c=0.206, P=0.001$ and $c c=0.180, P=0.001$ ) and negatively with the myoepithelial/basal phenotype marker CK5/6 (cc $=-0.120, P=0.001)$. No significant correlation was found with Her2, Ki-67 fraction or CD34-microvessel density.

Towards the prognostic value of $\mathrm{Mb}$ and clinicopathological parameters, a univariate Cox analysis confirmed histological tumour grade, pT stage, nodal status and hormone receptor $(\mathrm{ER} \alpha / \mathrm{PR})$ status as significant predictors of overall survival in our patient cohort (Supplementary Table 1). High Mb expression was also significantly associated with longer overall patient survival (5-year survival rate of $\mathrm{Mb}$-positive cases was $83 \%$ vs $75 \%$ in Mb-negative cases, Figure 2A), but lost significance in a multivariate Cox analysis that included pT, pN, BRE-grade, $\mathrm{ER} \alpha$ and $\mathrm{Mb}$ (not shown). In a multivariate survival analysis restricted to $\operatorname{ER} \alpha$, PR (as markers of luminal phenotype) and Mb, only PR remained a significant prognosticator $(\mathrm{HR}=0.62, P=0.004)$, whereas $\mathrm{Mb}$ yielded a trend towards a prognostic value $(\mathrm{HR}=0.75, P=0.06)$ and $\mathrm{ER} \alpha$ showed none at all $(\mathrm{HR}=0.74, P=0.11)$. However, in a Kaplan-Meier analysis stratifying tumours in groups that were either (a) negative for $E R \alpha$ and $M b$, (b) positive for $E R \alpha$ or $M b$ or (c) positive for both $\mathrm{ER} \alpha$ and $\mathrm{Mb}$, it became apparent that $\mathrm{Mb}$ does add some prognostic information to the ER status (Supplementary Figure S4), as tumours that were either positive for Mb or ER showed an intermediate course in comparison with tumours that were negative or positive for both markers $(P=0.001)$.

We additionally classified $\mathrm{Mb}$ levels in correlation with a publicly available breast cancer expression data set (Farmer et al, 2005) (GEO profiles, http://www.ncbi.nlm.nih.gov/sites/entrez, GDS1329). Here, Mb levels are significantly higher $(P=0.005$, Kruskal-Wallis test) in the group of luminal tumours compared with basal or apocrine types. These findings along with the positive correlation of $\mathrm{Mb}$ with $\mathrm{ER} \alpha$, the better tumour differentiation with improved prognosis and the negative correlation with the basal phenotype marker CK5/6 all point to $\mathrm{Mb}$ as a marker of luminal tumour differentiation. This association of $\mathrm{Mb}$ with characteristics of the luminal tumour subtype, namely, ER $\alpha$ positivity, led us to investigate this point further.

$\mathrm{Mb}$ expression is regulated by oestrogen signalling in silico and in vitro, and co-localises with the ER

Publicly available DNA array expression data (Geoprofiles, GDS2324) (Coser et al, 2003) had already indicated a tight co-regulation of $\mathrm{Mb}$ and $\mathrm{ER} \alpha \mathrm{mRNAs}$ in the breast cancer cell line MCF7 by showing that oestrogen starvation was able to induce, while oestrogen application suppressed, $\mathrm{Mb}$ and $\mathrm{ER} \alpha$ transcripts in either a time- or dose-dependent manner (Supplementary Figure S5; ER $\alpha=E S R 1$ in figure). We repeated this experiment and could confirm the in silico data in vitro also, in that application of 17- $\beta$ estradiol to $\mathrm{ER} \alpha$-positive MCF7 breast cancer cells repressed Mb expression dose dependently (Figure 2B).

This co-silencing of $\mathrm{ER} \alpha$ and $\mathrm{Mb}$ expression by oestrogen application to a breast cancer cell line prompted us to analyse the spatial association of both proteins by double immunofluorescence. In normal lobular breast parenchyma, $\sim 90 \%$ of the strongly Mb-positive secretory cells, interspersed in the secretory cell layer that we had already noted in the chromogenic immunohistochemistry, showed a cellular co-localisation (Figure 2E, left) of cytoplasmic $\mathrm{Mb}$ (Figure 2C, left) and nuclear ER $\alpha$ (Figure 2D, left) staining. In invasive breast carcinomas, this co-expression still was apparent in well-differentiated carcinomas (Figure 2E, right), whereas in moderately - poorly differentiated tumours, this overlap was less prominent (not statistically evaluated).

\section{Non-respiratory functions of non-muscle $\mathrm{Mb}$ ?}

The amount of $\mathrm{Mb}$ detected in human breast cancer tissue and MDA-MB468 cells was similar in western blot analysis (data not shown) and equalled $65 \mathrm{ng}$ per $10^{6}$ tumour cells, as described above. As this minute amount of $\mathrm{Mb}$ is unlikely to have a significant role in the maintenance of cellular oxygenation, $\mathrm{Mb}$ functions alternative to respiratory support have to be considered. Recently, Mb was described as a FA-binding protein and suggested to have a role in the transport of FAs in oxygenated cells (Gloster and Harris, 1977; Yackzan and Wingo, 1982; Masuda et al, 2008). This prompted us to investigate the possible co-localisation of $\mathrm{Mb}$ and FASN in both healthy and cancerous breast tissue. Fatty acid synthase catalyses the synthesis of unbranched FAs and is upregulated in the broad majority of malignant tumours (Menendez and Lupu, 2007). In a direct comparison of FASN expression with $\mathrm{Mb}$ in a subset $(n=293)$ of our breast cancer cohort, a highly significant correlation of both proteins was found ( $c c=0.297, P=0.001$ ). Moreover, in normal breast tissues, again, a striking spatial concordance in the expression of $\mathrm{Mb}$ and FASN was seen (Figure $3 \mathrm{~A}-\mathrm{C}$, left), which was also partially retained in cancer (Figure $3 \mathrm{~A}-\mathrm{C}$, right).

To check for a possible functional association of $\mathrm{Mb}$ expression and intracellular FA levels, we used the FASN inhibitor C75. This inhibitor has been characterised as FASN specific, leading to an almost immediate and irreversible enzyme inhibition (Kuhajda et al, 2000). In MDA-MB468 cells, we observed a strong timedependent downregulation of $\mathrm{Mb}$ on transcript (Figure 3D, left) and protein level (Figure 3D, right) on FASN inhibition in comparison with control cells, suggesting that non-muscle $\mathrm{Mb}$ expression is indeed regulated by intracellular FA levels. Thus, $\mathrm{Mb}$ in breast carcinomas and cancer cells might be involved in controlling FA metabolism.

\section{DISCUSSION}

This report is the first systematic examination of $\mathrm{Mb}$ expression in a large cohort of breast cancer specimens that allows clinical and molecular correlations and, furthermore, points to unexpected functional facets of this hemoprotein. We first noticed a supposedly aberrant $\mathrm{Mb}$ immunoreactivity in a small series of breast carcinomas. To address whether $\mathrm{Mb}$ is being actively produced by breast cancer cells or rather taken up from, for example, adjacent musculature, as suggested by Eusebi et al more than 25 years ago (Eusebi et al, 1984), we analysed its expression both in vitro and in vivo. On transcript level, we found $\mathrm{Mb}$ to be 
A

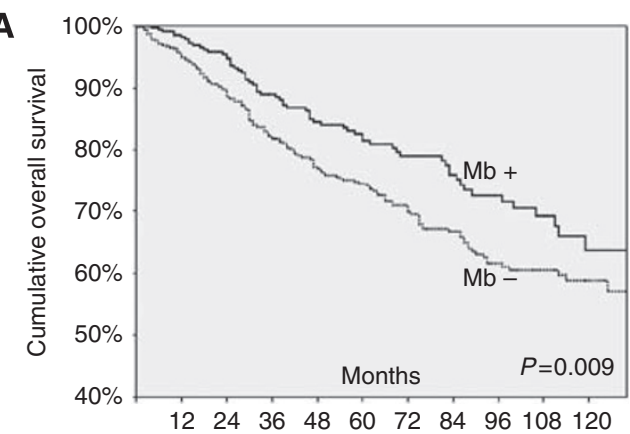

B

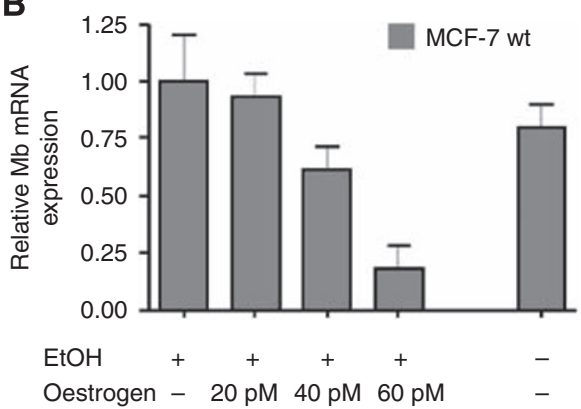

C

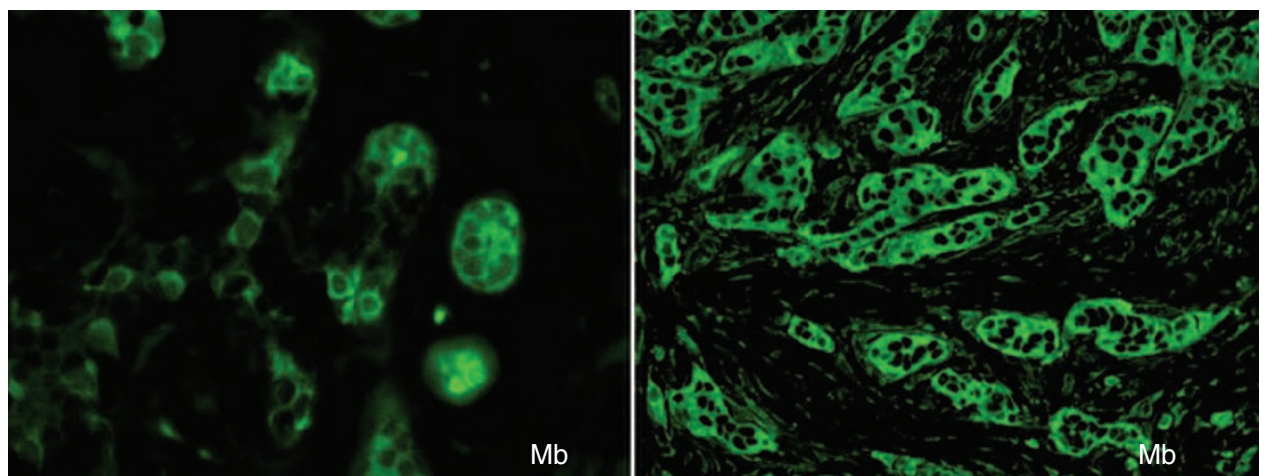

D

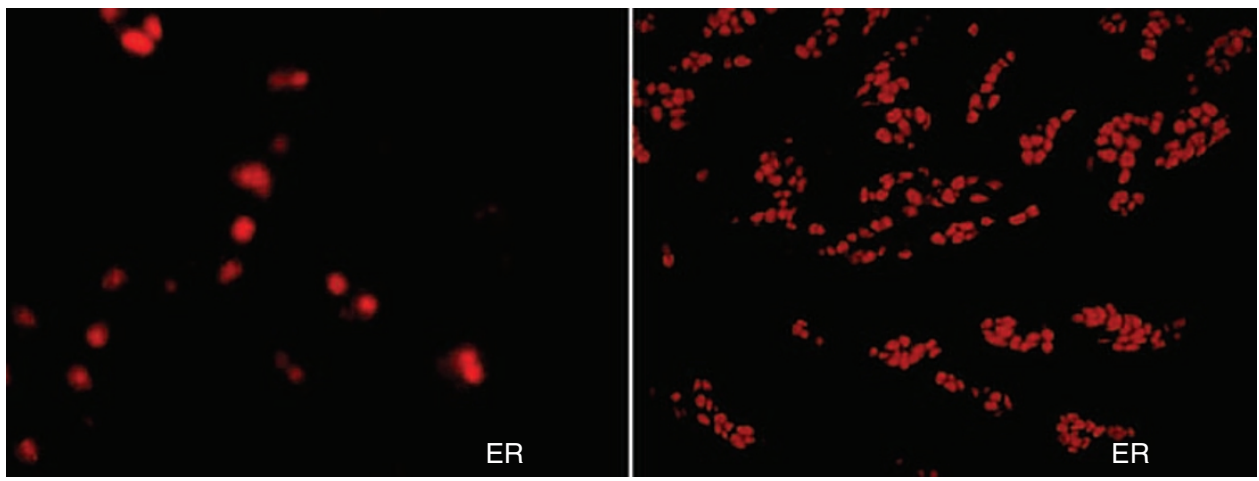

E
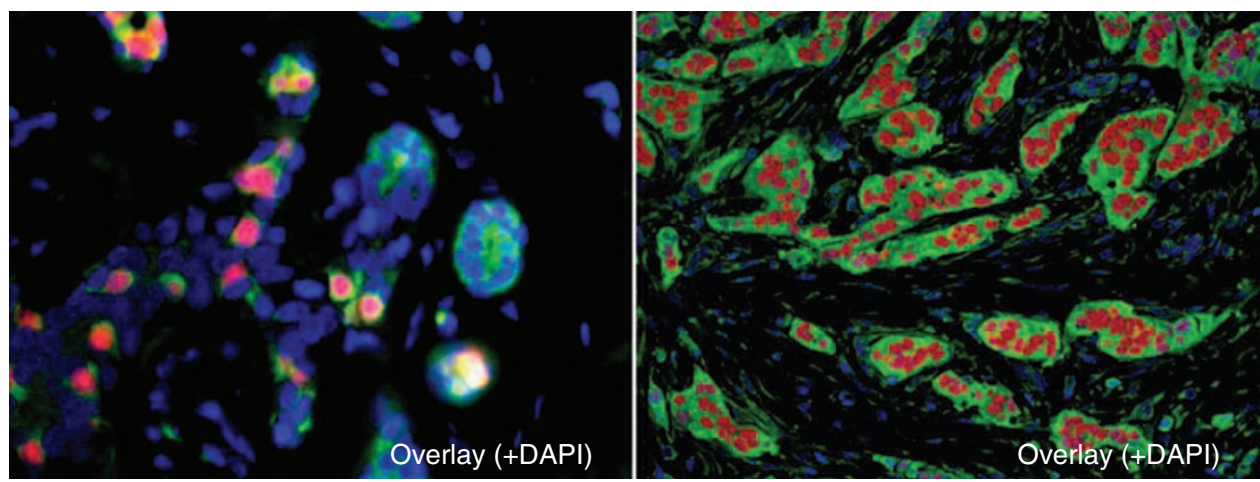

Figure 2 Myoglobin (Mb) expression is linked to better prognosis and oestrogen receptor (ER) positivity and inversely related to oestrogen concentration. (A) Kaplan-Meier analysis of a cohort of 917 primary breast cancer cases showing that tumours with high Mb expression (Mb + ) show a significant prognostic value for the patient of an improved cumulative overall survival compared with cases with low Mb expression (Mb-). (B) Myoglobin expression in MCF7 breast cancer cells is repressed by increasing concentrations of I7- $\beta$-estradiol (dissolved in ethanol), as measured by quantitative reverse transcription (RT)-PCR. (C) Normal breast tissue (left) shows a weak immunofluorescence for Mb in the secretory cell layer, of which some stronger staining cells are intermingled. (D) The immunofluorescence for $E R \alpha$ (left) shows nuclear staining of single cells also. (E)The merged figure (left) illustrates, that these cells, highlighted by ER $\alpha$ and Mb, are mostly corresponding (all $\times 400)$. (C-E) This co-expression is also shown in a well-differentiated invasive ductal breast carcinoma (panels on right hand side) $($ all $\times 200)$.

strongly upregulated in breast tumours in comparison with adjacent normal ductal tissue. Myoglobin mRNA was also detectable in breast cancer cell lines, in a small subset, even at surprisingly high levels. This underscored the active expression of endogenous $\mathrm{Mb}$ in ordinary invasive ductal breast cancer, which were neither muscle-invasive nor did they, as assessed by light 

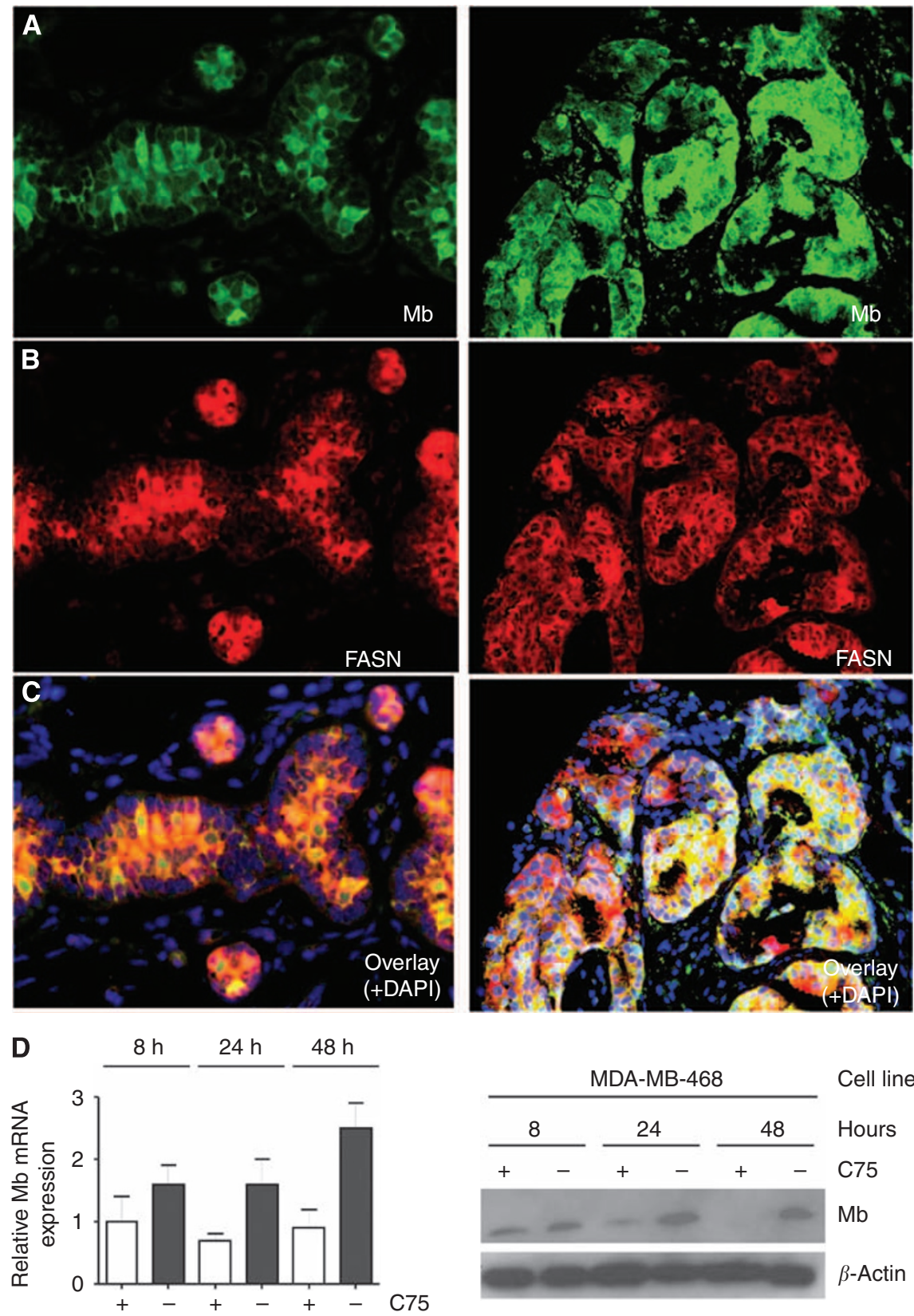

Figure 3 Double immunofluorescence (myoglobin (Mb)/fatty acid synthase (FASN)) staining of breast tissues and regulation of Mb by inhibition of FASN. (A) Normal breast tissue (panel on the left) shows weak immunofluorescence for $\mathrm{Mb}$ in the secretory cell layer, along with some stronger staining cells that are intermingled. (B) The immunofluorescence for FASN (middle) shows strong cytoplasmic staining. (C) The overlay figure (bottom) illustrates high degree of correspondence (yellow) between cells expressing Mb and FASN (all $\times 400$ ). In invasive carcinomas (panel on the right), a greater variation is seen and co-expression of $\mathrm{Mb}$ and FASN is only preserved in a subset of cells as the overlay illustrates. In general, the FASN expression exceeds Mb immunoreactivity (all $\times 200$ ). (D) Reverse transcription (RT)-PCR evidence for C75-mediated downregulation of Mb mRNA (left). Western blot evidence for C75-mediated downregulation of $\mathrm{Mb}$ protein (right).

microscopy, exhibit any rhabdomyogenous differentiation. Transmission electron microscopy also did not reveal any striated muscle elements in two strongly Mb-positive breast cancer cases. We therefore conclude that $\mathrm{Mb}$ is de novo expressed in breast cancer cells, although rare cases of so-called metaplastic carcinomas of the breast might exist in which $\mathrm{Mb}$ positivity stems from the rabdomyogenous differentiation of the cells (Jamieson and Rudland, 1990; Yang et al, 2003).

On the basis of these encouraging preliminary findings, a large recently described (Theurillat et al, 2007) cohort of primary breast cancer, including 917 cases of invasive carcinomas and 155 cases of
DCIS, was analysed for $\mathrm{Mb}$ expression. Specificity of the $\mathrm{Mb}$ antibody was confirmed through the peptide blockage of the immunohistochemical signal (Supplementary Figure S1). In total, $40 \%$ of invasive carcinomas showed moderate-to-strong $\mathrm{Mb}$ expression and the rate is even slightly higher in DCIS. However, $\mathrm{Mb}$ was also consistently seen in mature secretory epithelia of the healthy breast, showing a basal expression in most cells and with a particularly pronounced expression in ER $\alpha$-positive cells, as we noted later. Contrary to earlier reports that found normal epithelia to be invariably $\mathrm{Mb}$ negative (Flonta et al, 2009), luminal cells in healthy breast clearly have the ability to express $\mathrm{Mb}$ at detectable 
levels. The recently published study of Flonta et al (2009), which was published during the preparation of this paper, identified endogenous $\mathrm{Mb}$ in various human cancer cell lines and human epithelial tumours including breast cancer and elucidated several signals, including NO, oxidative stress and mitogens (EGF and serum growth factors) and also hypoxia, that were able to stimulate Mb expression in cultivated MCF7 breast cancer cells. However, their study, which encompassed only 31 breast cancer cases, lacked any prognostic or detailed clinicopathological data.

Regarding its occurrence in breast cancer, we found that $\mathrm{Mb}$ is preferentially detected in better-differentiated, hormone receptorpositive tumours and is associated with a significantly better prognosis. According to Perou et al (2000), all these features are characteristics of the so-called luminal subtype of breast cancer, which shares many molecular similarities with normal secretory epithelia, including a strong expression of cytokeratins typical of mature secretory epithelia (CK8/18), hormone receptor (ER $\alpha / \mathrm{PR})$ positivity and negativity for HER2 and the basal cell cytokeratins $\mathrm{CK} 5 / 6$. Further support for considering $\mathrm{Mb}$ as a diagnostic marker of the luminal breast cancer subtype comes from the in silico analysis of Farmer et al's data, in which Mb transcript levels were highest in tumours classified as the luminal subtype (Farmer et al, 2005). Our immunofluorescent double stainings further detected co-localisation of cytoplasmic $\mathrm{Mb}$ and nuclear $\mathrm{ER} \alpha$ in secretory cells of normal breast tissue. The same intracellular co-localisation was found in strongly $\mathrm{Mb}$ - and $\mathrm{ER} \alpha$-positive invasive ductal carcinomas. Beyond this spatial co-existence, $\mathrm{Mb}$ and $\mathrm{ER} \alpha$ transcripts are also co-ordinately and dose-dependently downregulated when MCF7 cells are subjected to an oestrogenic (E2 $=17-\beta$-estradiol) treatment protocol, as shown by in silico (Supplementary Figure S5) and in vitro (Figure 3B) analyses. In this context, it is of relevance to highlight the observation of Cheng et al (2005), who described the inverse relationship of E2 and ER $\alpha$ (which we found to be co-expressed with $\mathrm{Mb}$ ) levels in normal breast epithelia during the mammalian menstrual cycle. These authors further point out that elevated expression of $\mathrm{ER} \alpha$, occurring, for example, in postmenopausal women as a result of the loss of E2 signalling, is indicative of non-proliferating breast cells. The hitherto undescribed co-regulation of Mb with ER $\alpha$ by oestrogen likely underlies the co-expression of $\mathrm{ER} \alpha$ with $\mathrm{Mb}$ in differentiated luminal cells with their reduced proliferation, which, in turn, might explain the favourable prognosis of Mb-positive tumours. The negative association of tumoural $\mathrm{Mb}$ expression and a pre-menopausal status further fits the interpretation of $\mathrm{Mb}$ as an oestrogen-silenced gene, as pre-menopausal patients (high oestrogen serum levels) have, in comparison with postmenopausal patients (lower oestrogen serum levels), tumours with lower $\mathrm{Mb}$ expression levels. In any instance, as the prognostic value of $\mathrm{Mb}$ is limited in comparison with ER or PR, we do not suggest its use as a primary marker to identify luminal phenotype carcinomas for therapy planning. However, $\mathrm{Mb}$ might gain clinical relevance if it could be validated as a novel therapy target of cancer, for example, by applying carbon monoxide in sub-toxic concentrations, as has been suggested by Dr Wittenberg at the O2BIP meeting in Aarhus in 2008, which clearly warrants further study. This is more important, as luminal-type breast cancer, although generally more favourable in course, does not respond well to conventional chemotherapy (Bhargava et al, 2010).

Myoglobin has different known or alleged functions in muscle tissue including short-term $\mathrm{O}_{2}$ storage and buffering, facilitating $\mathrm{O}_{2}$ diffusion, scavenging of NO and ROS and also the reverse (peroxidase activity, NO production) and might be involved in FA metabolism (Wittenberg, 1970; Wittenberg et al, 1975; Khan et al, 1998; Flögel et al, 2001, 2004; Ordway and Garry, 2004; HendgenCotta et al, 2008; Masuda et al, 2008). The functions of Mb in nonmuscle tissues are elusive so far. More than 50 years after Thomlinson's and Gray's pioneering discovery to link radio- sensitivity with $\mathrm{O}_{2}$ tension in tumour tissue (Gray et al, 1953; Thomlinson and Gray, 1955), the existence of regional hypoxia in most solid tumours (for review see Vaupel et al, 1991; Thews et al, 1998; Brown, 1999; Brown and Wilson, 2004) including breast cancer is of high clinical relevance (Vaupel et al, 1992). Using the exogenous hypoxia marker pimonidazole, Arcasoy et al (2002) concluded from a series of 26 breast cancer cases that $62 \%$ of tumours of the breast are pimonidazole-positive and thus hypoxic. As this rate of positivity is in the range of $\mathrm{Mb}$ positivity that we observed in breast cancer, we had originally hypothesised to find an association of $\mathrm{Mb}$ with tissue hypoxia. In addition, the demonstration of hypoxia-driven $\mathrm{Mb}$ induction in a cell line model by Flonta et al (2009) fitted this interpretation very well. However, our in vivo data, correlating $\mathrm{Mb}$ expression with acknowledged endogenous markers of hypoxia, revealed a rather more complex and heterogeneous picture. There was no correlation with HIF- $1 \alpha$ and its target gene GLUT1, which could either mean that $\mathrm{Mb}$ is not significantly regulated by hypoxia in vivo or that HIF- $1 \alpha$ is insufficiently present and active because of the amelioration of tissue hypoxia by expressed $\mathrm{Mb}$. However, given the picomole concentrations of $\mathrm{Mb}$ protein that we have measured per million of the maximal Mb-producing MDA-MB468 cell line (Figure 1B), the latter scenario is rather unlikely to explain this lack of correlation. On the other hand, there is a significant correlation of Mb to HIF- $2 \alpha$ and the HIF-1/HIF-2 target gene CAIX, which is in line of at least a partial control of $\mathrm{Mb}$ expression by hypoxia. Yet, expression of $\mathrm{Mb}$ in breast epithelia can clearly be regulated irrespective of $\mathrm{O}_{2}$ levels (that is, signals in normal secretory ductal cells). The fact that $\mathrm{Mb}$ in breast malignancies links with HIF- $2 \alpha$ rather than HIF- $1 \alpha$ results perhaps from the mutually exclusive status between active HIF- $1 \alpha$ and ER $\alpha / \mathrm{PR}$ signalling in breast cancer cells (Kurebayashi, 2003; MassaadMassade, 2004). In this sense, it is the positive correlation between $\mathrm{Mb}$ and $\mathrm{ER} \alpha / \mathrm{PR}$ positivity that might preclude a significant linkage of Mb with HIF- $1 \alpha$. All this evidence only underscores the complex regulation of the $\mathrm{Mb}$ gene in breast carcinomas, in which hypoxia/ HIF signalling is just one of several stimuli to modulate the abundance of this hemoprotein.

To our knowledge, so far only two studies have investigated the functions of $\mathrm{Mb}$ in vivo models using artificial $\mathrm{Mb}$ expression systems. Nitta et al (2003) induced Mb expression in hepatocytes by an adenoviral gene transfer in rodents, with the effect that these hepatocytes were significantly more hypoxia resistant. Galluzzo et al (2009) were the first to introduce Mb into tumour cell lines and engineered A549 human lung carcinoma cells to ectopically express mouse $\mathrm{Mb}$. Their experimental Mb-expressing tumours displayed reduced or no hypoxia, minimal HIF-1 $\alpha$ levels, decreased vessel density and finally a more differentiated cancer cell phenotype. In addition, largely suppressed local and distal metastatic spreading was observed. The authors assume that these beneficial outcomes of $\mathrm{Mb}$ overexpressing tumours result primarily from the reduction of tumour hypoxia (Galluzzo et al, 2009). Although it is tempting to compare their mouse model in vivo findings with our in vivo observations from human patients, given that higher $\mathrm{Mb}$ levels correlate with less aggressive tumour behaviour, both situations are quite different. We have estimated the amount of endogenous $\mathrm{Mb}$ in normoxic MDA-MB468 breast cancer cells to equate to $\sim 65 \mathrm{ng}$ or 4 pmol of $\mathrm{Mb}$ protein present in $10^{6}$ cells. This quantity is certainly far below the high micromolar levels reached by the lentiviral gene transfer (Galluzzo et al, 2009). Although such excessive amounts of ectopic $\mathrm{Mb}$ in tumour cells can, with reason, be assumed to have a significant impact on tumour respiration and tumour growth, the endogenous picomole quantities of $\mathrm{Mb}$ we detected are unlikely to confer meaningful $\mathrm{O}_{2}$ storage/buffering capacity to the cell, as already mentioned above. Thus, for these cells, functions of $\mathrm{Mb}$ that are not directly linked to the binding and transport of $\mathrm{O}_{2}$ have to be considered to understand the physiological relevance of this protein in breast cancer. 
One of the functions of $\mathrm{Mb}$ that might also be tremendously relevant for tumour cells is the control of FA metabolism. In a multitude of tumours, growth is accompanied with increased FA synthesis, and consequently enzymes catalysing these steps are upregulated and can be used diagnostically and therapeutically (for recent reviews see Menendez and Lupu, 2007 and Mashima et al, 2009). We discovered that the co-localisation of $\mathrm{Mb}$ with FASN might give a hint towards the FA-binding function of tumour $\mathrm{Mb}$. Fatty acid-binding properties of $\mathrm{Mb}$ have been reported and predicted early (Lewis et al, 1968; Gloster and Harris, 1977), and have recently gained further attention (Sriram et al, 2008). According to Flögel et al (2005), lack of Mb in the heart of knockout mice leads to a biochemical shift in cardiac substrate utilisation from FA to glucose oxidation, which, not only corresponds to an adaptive reduction in $\mathrm{O}_{2}$ consumption for the equimolar production of ATP but also implicates the protein in providing FA substrates for the mitochondrial $\beta$-oxidation breakdown in vivo. Our indirect demonstration that $\mathrm{Mb}$ is likely to be regulated by intracellular FA levels, as shown by the inhibition of FASN, now indicates a putative role for $\mathrm{Mb}$ in $\mathrm{FA}$ metabolism of cancer cells and clearly warrants further study. Analysing the metabolomic profiles of $\mathrm{Mb}$-positive and $\mathrm{Mb}$-negative breast cancer cases should also yield relevant data to shed more light on the putative role of $\mathrm{Mb}$ in FA metabolism.

In summary, $\mathrm{Mb}$ is endogenously expressed in normal breast tissue and abundantly in a subset of breast cancer cases. The strong association of $\mathrm{Mb}$ expression with presence of the ER $\alpha$ explains the generally better prognosis of Mb-positive tumours, compared with tumours lacking Mb. It appears that the regulation of $\mathrm{Mb}$ in tumours is so far only incompletely understood. Our data suggests that in breast cancer cells, $\mathrm{Mb}$ expression is regulated by oestrogen signalling, possibly also by FA levels and hypoxia. The prospective role of $\mathrm{Mb}$ in the lipid metabolism of ERpositive tumours provides a reasonable rationale to investigate this association in further studies, yet the role of other stimuli, for example, NO or growth factors, also needs to be looked at in greater detail. Taken together, these findings further broaden our view on the role of non-muscle $\mathrm{Mb}$ that may have fundamental implications for our conception of the biology of solid tumours.

\section{ACKNOWLEDGEMENTS}

The excellent technical assistance of Britta Beyer, Annette Bohnert, Martina Bimmler, Martina Storz, Silvia Behnke, Sonja von Serenyi and Daniela Wichmann is thankfully acknowledged. We also thank Katharina Spanaus (Institute of Clinical Chemistry, USZ) for help and advice. Parts of this work were funded by a grant of Faculty of Medicine (ED), RWTH Aachen (START network on tumour marker and their function).

Supplementary Information accompanies the paper on British Journal of Cancer website (http://www.nature.com/bjc)

\section{REFERENCES}

Arcasoy MO, Amin K, Karayal AF, Chou SC, Raleigh JA, Varia MA, Haroon ZA (2002) Functional significance of erythropoietin receptor expression in breast cancer. Lab Invest 82: $911-918$

Bhargava R, Beriwal S, Dabbs DJ, Ozbek U, Soran A, Johnson RR, Brufsky AM, Lembersky BC, Ahrendt GM (2010) Immunohistochemical surrogate markers of breast cancer molecular classes predicts response to neoadjuvant chemotherapy: a single institutional experience with 359 cases. Cancer 116: $1431-1439$

Brown JM (1999) The hypoxic cell: a target for selective cancer therapyeighteenth Bruce F. Cain Memorial Award lecture. Cancer Res 59: $5863-5870$

Brown JM, Wilson WR (2004) Exploiting tumour hypoxia in cancer treatment. Nat Rev Cancer 4: 437-447

Brunori M (2001) Nitric oxide moves myoglobin centre stage. Trends Biochem Sci 26: 209-210

Cheng G, Li Y, Omoto Y, Wang Y, Berg T, Nord M, Vihko P, Warner M, Piao YS, Gustafsson JA (2005) Differential regulation of estrogen receptor (ER)alpha and ERbeta in primate mammary gland. J Clin Endocrinol Metab 90: 435 - 444

Coser KR, Chesnes J, Hur J, Ray S, Isselbacher KJ, Shioda T (2003) Global analysis of ligand sensitivity of estrogen inducible and suppressible genes in MCF7/BUS breast cancer cells by DNA microarray. Proc Natl Acad Sci USA 100: $13994-13999$

Elston EW, Ellis IO (1993) Method for grading breast cancer. J Clin Pathol 46: $189-190$

Eusebi V, Bondi A, Rosai J (1984) Immunohistochemical localization of myoglobin in nonmuscular cells. Am J Surg Pathol 8: $51-55$

Farmer P, Bonnefoi H, Becette V, Tubiana-Hulin M, Fumoleau P, Larsimont D, Macgrogan G, Bergh J, Cameron D, Goldstein D, Duss S, Nicoulaz AL Brisken C, Fiche M, Delorenzi M, Iggo R (2005) Identification of molecular apocrine breast tumours by microarray analysis. Oncogene 24: $4660-4671$

Flögel U, Gödecke A, Klotz LO, Schrader J (2004) Role of myoglobin in the antioxidant defense of the heart. FASEB J 18: 1156-1158

Flögel U, Laussmann T, Gödecke A, Abanador N, Schafers M, Fingas CD, Metzger S, Levkau B, Jacoby C, Schrader J (2005) Lack of myoglobin causes a switch in cardiac substrate selection. Circ Res 96: e68-e75
Flögel U, Merx MW, Gödecke A, Decking UK, Schrader J (2001) Myoglobin: a scavenger of bioactive NO. Proc Natl Acad Sci USA 98: 735-740

Flonta SE, Arena S, Pisacane A, Michieli P, Bardelli A (2009) Expression and functional regulation of myoglobin in epithelial cancers. Am J Pathol 175: $201-206$

Galluzzo M, Pennacchietti S, Rosano S, Comoglio PM, Michieli P (2009) Prevention of hypoxia by myoglobin expression in human tumor cells promotes differentiation and inhibits metastasis. J Clin Invest 119: 865 - 875

Garry DJ, Ordway GA, Lorenz JN, Radford NB, Chin ER, Grange RW, Bassel-Duby R, Williams RS (1998) Mice without myoglobin. Nature 395: 905-908

Gloster J, Harris P (1977) Fatty acid binding to cytoplasmic proteins of myocardium and red and white skeletal muscle in the rat. A possible new role for myoglobin. Biochem Biophys Res Commun 74: 506-513

Gödecke A, Flögel U, Zanger K, Ding Z, Hirchenhain J, Decking UK, Schrader J (1999) Disruption of myoglobin in mice induces multiple compensatory mechanisms. Proc Natl Acad Sci USA 96: 10495-10500

Gray LH, Conger AD, Ebert M, Hornsey S, Scott OC (1953) The concentration of oxygen dissolved in tissues at the time of irradiation as a factor in radiotherapy. $\mathrm{Br} J$ Radiol 26: 638-648

Hendgen-Cotta UB, Merx MW, Shiva S, Schmitz J, Becher S, Klare JP, Steinhoff HJ, Goedecke A, Schrader J, Gladwin MT, Kelm M, Rassaf T (2008) Nitrite reductase activity of myoglobin regulates respiration and cellular viability in myocardial ischemia-reperfusion injury. Proc Natl Acad Sci USA 105: 10256-10261

Iseki M, Tsuda N, Kishikawa M, Shimada O, Hayashi T, Kawahara K, Tomita M (1990) Thymolipoma with striated myoid cells. Histological, immunohistochemical, and ultrastructural study. Am J Surg Pathol 14: $395-398$

Jamieson S, Rudland PS (1990) Identification of metaplastic variants generated by transfection of a nonmetastatic rat mammary epithelial cell line with DNA from a metastatic rat mammary cell line. Am J Pathol 137: $629-641$

Jürgens KD, Peters T, Gros G (1994) Diffusivity of myoglobin in intact skeletal muscle cells. Proc Natl Acad Sci USA 91: 3829-3833

Kendrew JC (1958) Architecture of a protein molecule. Nature 182: $764-767$ 
Khan KK, Mondal MS, Padhy L, Mitra S (1998) The role of distal histidine in peroxidase activity of myoglobin-transient-kinetics study of the reaction of $\mathrm{H} 2 \mathrm{O} 2$ with wild-type and distal-histidine-mutanted recombinant human myoglobin. Eur J Biochem 257: 547 - 555

Kristiansen G, Fritzsche FR, Wassermann K, Jager C, Tolls A, Lein M, Stephan C, Jung K, Pilarsky C, Dietel M, Moch H (2008) GOLPH2 protein expression as a novel tissue biomarker for prostate cancer: implications for tissue-based diagnostics. Br J Cancer 99: 939-948

Kuhajda FP, Pizer ES, Li JN, Mani NS, Frehywot GL, Townsend CA (2000) Synthesis and antitumor activity of an inhibitor of fatty acid synthase. Proc Natl Acad Sci USA 97: 3450-3454

Kurebayashi J (2003) Endocrine-resistant breast cancer: underlying mechanisms and strategies for overcoming resistance. Breast Cancer 10: $112-119$

Lewis UJ, Cheever EV, Seavey BK (1968) Influence of fatty acids on the electrophoretic behavior of proteins with special reference to pituitary hormone and thyroglobulin. J Biol Chem 243: 260-267

Mashima T, Seimiya H, Tsuruo T (2009) De novo fatty-acid synthesis and related pathways as molecular targets for cancer therapy. Br J Cancer 100: $1369-1372$

Massaad-Massade L (2004) [Hypoxia, HIF1alpha and estrogen receptor]. Bull Cancer 91: 677-683

Masuda K, Truscott K, Lin PC, Kreutzer U, Chung Y, Sriram R, Jue T (2008) Determination of myoglobin concentration in blood-perfused tissue. Eur J Appl Physiol 104: $41-48$

Menendez JA, Lupu R (2007) Fatty acid synthase and the lipogenic phenotype in cancer pathogenesis. Nat Rev Cancer 7: 763-777

Nitta T, Xundi X, Hatano E, Yamamoto N, Uehara T, Yoshida M, Harada N, Honda K, Tanaka A, Sosnowski D, Chance B, Yamaoka Y (2003) Myoglobin gene expression attenuates hepatic ischemia reperfusion injury. J Surg Res 110: $322-331$

Ordway GA, Garry DJ (2004) Myoglobin: an essential hemoprotein in striated muscle. J Exp Biol 207: 3441 - 3446

Perou CM, Sorlie T, Eisen MB, van de Rijn M, Jeffrey SS, Rees CA, Pollack JR, Ross DT, Johnsen H, Akslen LA, Fluge O, Pergamenschikov A, Williams C, Zhu SX, Lonning PE, Borresen-Dale AL, Brown PO, Botstein D (2000) Molecular portraits of human breast tumours. Nature 406: $747-752$

Ruck P, Horny HP, Greschniok A, Wehrmann M, Kaiserling E (1995) Nonspecific immunostaining of blast cells of acute leukemia by antibodies against nonhemopoietic antigens. Hematol Pathol 9: 49-56

Smith TW, Davidson RI (1984) Medullomyoblastoma. A histologic, immunohistochemical, and ultrastructural study. Cancer 54: 323 - 332
Sobin LH, Wittekind Ch (eds) (2002) TNM Classification of Malignant Tumours. Wiley-Liss, Inc.: New York

Sriram R, Kreutzer U, Shih L, Jue T (2008) Interaction of fatty acid with myoglobin. FEBS Lett 582: 3643 - 3649

Tavassoli FA, Devilee P (eds) (2003) World Health Organization Classification of Tumours. Pathology and Genetics of Tumours of the Breast and Female Genital Organs. IARC Press: Lyon

Theurillat JP, Ingold F, Frei C, Zippelius A, Varga Z, Seifert B, Chen YT, Jager D, Knuth A, Moch H (2007) NY-ESO-1 protein expression in primary breast carcinoma and metastases: correlation with CD8+ T-cell and CD79a+ plasmacytic/B-cell infiltration. Int J Cancer 120: $2411-2417$

Thews O, Koenig R, Kelleher DK, Kutzner J, Vaupel P (1998) Enhanced radiosensitivity in experimental tumours following erythropoietin treatment of chemotherapy-induced anaemia. $\mathrm{Br} J$ Cancer 78: $752-756$

Thomlinson RH, Gray LH (1955) The histological structure of some human lung cancers and the possible implications for radiotherapy. $\mathrm{Br} \mathrm{J}$ Cancer 9: $539-549$

Vaupel P, Schlenger K, Knoop C, Hockel M (1991) Oxygenation of human tumors: evaluation of tissue oxygen distribution in breast cancers by computerized $\mathrm{O} 2$ tension measurements. Cancer Res 51: 3316-3322

Vaupel P, Schlenger KH, Hoeckel M, Okunieff P (1992) Oxygenation of mammary tumors: from isotransplanted rodent tumors to primary malignancies in patients. Adv Exp Med Biol 316: $361-371$

Veeck J, Niederacher D, An H, Klopocki E, Wiesmann F, Betz B, Galm O, Camara O, Durst M, Kristiansen G, Huszka C, Knuchel R, Dahl E (2006) Aberrant methylation of the Wnt antagonist SFRP1 in breast cancer is associated with unfavourable prognosis. Oncogene 25: 3479-3488

Wittenberg BA, Wittenberg JB, Caldwell PR (1975) Role of myoglobin in the oxygen supply to red skeletal muscle. J Biol Chem 250: 9038-9043

Wittenberg JB (1970) Myoglobin-facilitated oxygen diffusion: role of myoglobin in oxygen entry into muscle. Physiol Rev 50: 559-636

Yackzan KS, Wingo WJ (1982) Transport of fatty acids by myoglobin- a hypothesis. Med Hypotheses 8: 613-618

Yang GC, Yee HT, Waisman J (2003) Metaplastic carcinoma of the breast with rhabdomyosarcomatous element: aspiration cytology with histological, immunohistochemical, and ultrastructural correlations. Diagn Cytopathol 28: $153-158$

Zhang PJ, Goldblum JR, Pawel BR, Fisher C, Pasha TL, Barr FG (2003) Immunophenotype of desmoplastic small round cell tumors as detected in cases with EWS-WT1 gene fusion product. Mod Pathol 16: $229-235$ 